\title{
Plant secondary succession age-related changes in landfills
}

\section{Patricia Gantes, Liliana B. Falco, Carlos E. Coviella \& Aníbal Sánchez Caro}

\section{Urban Ecosystems}

ISSN 1083-8155

Urban Ecosyst

DOI 10.1007/s11252-014-0366-z

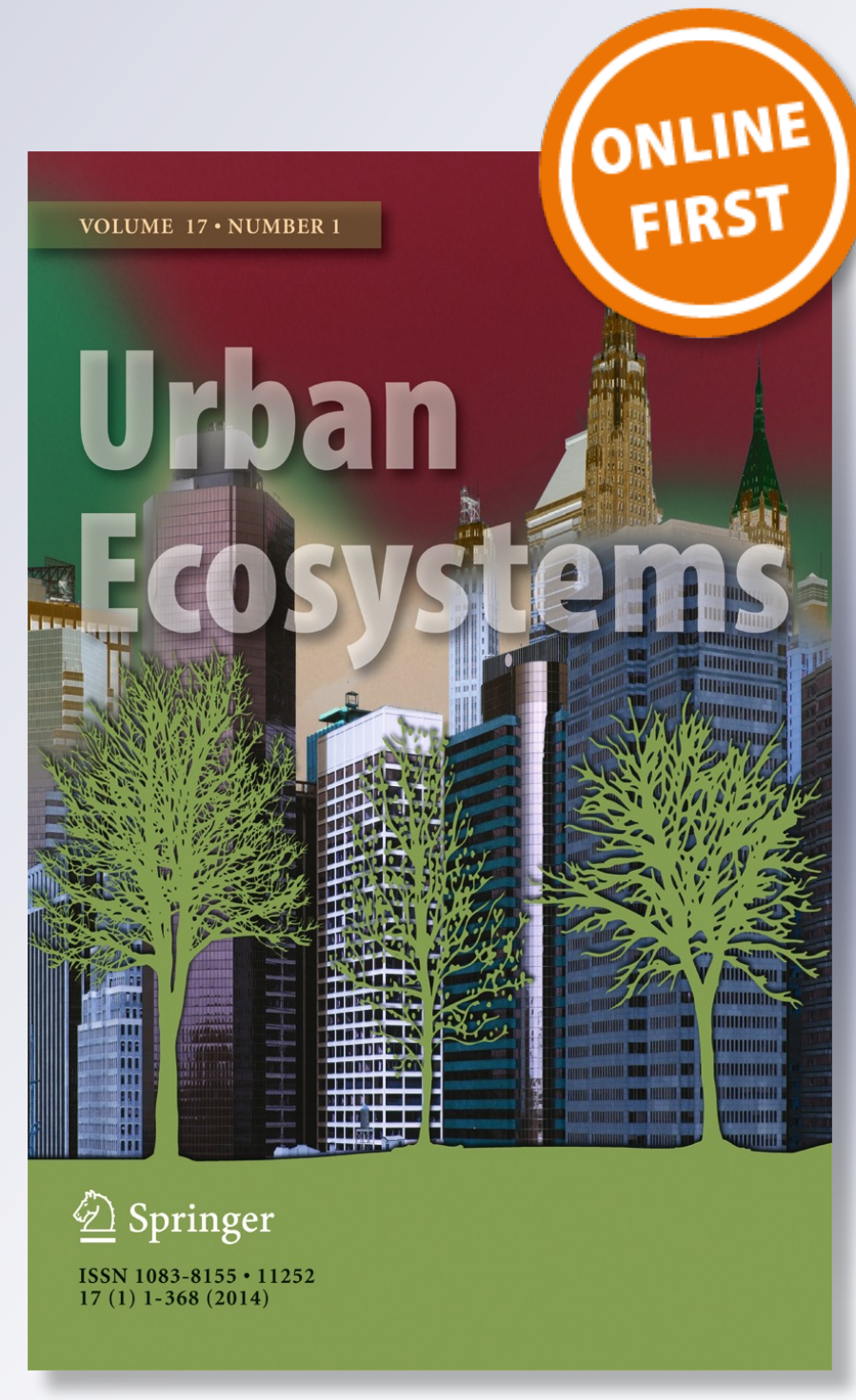

囪 Springer 
Your article is protected by copyright and all rights are held exclusively by Springer Science +Business Media New York. This e-offprint is for personal use only and shall not be selfarchived in electronic repositories. If you wish to self-archive your article, please use the accepted manuscript version for posting on your own website. You may further deposit the accepted manuscript version in any repository, provided it is only made publicly available 12 months after official publication or later and provided acknowledgement is given to the original source of publication and a link is inserted to the published article on Springer's website. The link must be accompanied by the following text: "The final publication is available at link.springer.com". 


\title{
Plant secondary succession age-related changes in landfills
}

\author{
Patricia Gantes • Liliana B. Falco • Carlos E. Coviella • \\ Aníbal Sánchez Caro
}

(C) Springer Science+Business Media New York 2014

\begin{abstract}
Sanitary landfills are widely used for large-scale final disposal of municipal wastes. The material covering the wastes is diverse in nature and bears propagules of different plant species, which develops spontaneously on the sites after waste disposal stops. The aim of this study was to detect the main patterns of vegetation secondary succession over the landfill cells, despite the differences in area and surface work intensity at the landfills. Over the span of two years, eight samplings were carried out on each of the 13 cells from the three active landfills in Buenos Aires. The relative cover for each plant species and the soil's mechanic resistance were registered. The vegetation cover reached $80 \%$ after five years and a decrease in soil's mechanic resistance was observed 5 years after closure. Regarding the floristic composition of the assemblages, most of the herbaceous species found were native $(42 \%)$ and perennials $(62 \%)$. The dominant species in all the cells was Cynodon dactylon. The heterogeneity of the assemblages between the three places prevented the configuration of an age linked pattern. However, some regularities arise: exotics are dominant along the whole succession; meanwhile, natives gain in proportionality consistently with the age of the cells. Most of the dominant species are characteristic of perturbed environments, but in the oldest cells some species belong to the climax pampean steppe; so, an orientated human intervention would be necessary to achieve a dominance of natives.
\end{abstract}

Keywords Landfills $\cdot$ Technosols $\cdot$ Vegetation cover · Diversity $\cdot$ Native species

\section{Introduction}

Sanitary landfills are one of the most widely used technologies for large scale final disposal of municipal solid wastes (MSW) worldwide. One of the long-term problems posed by this technology is the final destination of the terrains after the sanitary landfills are closed. In some

Electronic supplementary material The online version of this article (doi:10.1007/s11252-014-0366-z) contains supplementary material, which is available to authorized users.

P. Gantes $(\bowtie) \cdot$ L. B. Falco $\cdot$ C. E. Coviella $\cdot$ A. S. Caro

Laboratorio de Ecología, Departamento de Ciencias Básicas e Instituto de Ecología y Desarrollo Sustentable (INEDES), Universidad Nacional de Luján, Av. Constitución y Ruta 5, 6700 Luján, Buenos Aires,

Argentina

e-mail: gantespat@yahoo.com.ar 
places, these sites are re-used as spaces for recreational activities, such as golfing, or landscaped for other community uses. Thus, both the level of vegetation cover and the species composition become of fundamental importance, by preventing the erosion of the substratum that first covers the wastes, favoring soil formation, and facilitating the establishment of plant species which improve the visual quality of the landscape after landfill closure.

For the closed landfills to be used recreationally, the vegetation cover must be complete. Sometimes, however, this objective cannot be achieved due to gas emissions, leachates, or to the characteristic lack of soil structure of the landfills (Lan and Wong 1994; Trotter and Cooke 2005). The cover with which the wastes are covered can be considered a technosol (Lehmann and Stahr 2007), resulting from different types of materials, and having different characteristics from those of the site's natural soils (Hartley et al. 2008). The vegetation cover contributes to the formation of a soil which, in the long term, will allow the establishment of a vegetal assemblage whose diversity might be higher than that of the urban reference sites (Chan et al. 1997; Simmons 1999).

While a landfill is active, the surface of its cells —either those still being filled or those already closed - suffer frequent and widespread disturbances, mainly related to the machinery movements necessary for the installation and maintenance of the structures that degasify and extract leachates. Long after the landfills are closed, activities such as degasification and the extraction of leachates persist, along with the periodic disturbance caused by the process of grass cutting.

The cover material of the dumpsites bear propagules of different species, some of which can get established and expand themselves on the closed cells, where wastes have been deposited. Over time, seeds and other propagules can also reach the dumpsite from elsewhere, and other plant species can colonize the place and get established. The dynamics of the vegetation in the cells can be interpreted as a spontaneous secondary succession, which begins right after the deposit of the naked substratum, and during which both the composition and structure of the vegetation change. It is of interest to know whether, as succession progresses, the structure and composition of the vegetation changes towards that of the native flora or remains close to that of altered sites.

The city of Buenos Aires (Argentina) and many municipalities of the metropolitan area carry out the final disposal of their solid urban wastes in a few sanitary landfills, where the waste is buried. First done in Argentina in the mid 70's, this activity put an end to the domiciliary burnings of MSW that took place in the city of Buenos Aires, and decreased the number of burnings of urban wastes which took place in other districts.

At present, there are three active sanitary landfills that receive very different daily amounts of MSW. The cells are continuously covered by soil of a heterogeneous quality, a substrate which, unlike what happens in other landfills, is not sown.

The objective of this study was to detect the main patterns of the vegetation secondary succession over the landfill cells, despite the differences in area and surface work intensity at the three landfills. Plant cover, plant assemblage structure and soil mechanical resistance were assessed. In order to do this, our approach was to study synchronically how the cover and the diversity of the vegetation varied in cells of different ages, from the point when the cell is active (age 0 ) up to 23 years after cell closure, which is the maximum cell age registered in the studied landfills.

\section{Study area}

Two of the landfills are located within the Metropolitan Area of Buenos Aires (MABA), and the third one is located in the outskirts of the city of La Plata. Although these areas are mostly 
urbanized, the landfill near La Plata lays close to the Río de la Plata shore and to the protected area Punta Lara Natural Preserve. The original prevailing vegetation of the region is the Pampean steppe, with high dominance of gramineous species where more than 550 grasses have been described. This system has been almost completely modified or replaced for human ends (agriculture and cattle raising) with very few patches of natural vegetation or protected areas (Cabrera and Willink 1980; Bilenca and Miñarro 2004; Martino, 2004). The other natural ecosystem present in the area is the so-called Selva Marginal, a relictual forest which develops on the Río de la Plata shore, linked to the Paraná River basin. The Punta Lara Natural Preserve aims to safeguard this system.

During the year 2010, the three landfills received a total of 6,125,506 metric tons of MSW, coming from the Autonomous City of Buenos Aires, the 34 municipalities of the MABA, and 4 municipalities around La Plata (CEAMSE 2011). According to the last census, these urban areas hold a total population of 14,424,064 inhabitants and 5,218,085 households (INDEC 2010). This implies that an average of $1.16 \mathrm{~kg}$ of MSW per capita or $3.22 \mathrm{~kg}$ of MSW per household are deposited daily in the three landfills, where they are buried in landfill cells.

Landfill 1 started receiving MSW in 1994. It has a surface of approximately 242 ha, and it is divided into four reception cells, aged between 0 and 5 years, two of which are in a postclosure stage and no longer receive wastes. During 2010, it received approximately $88 \%$ of the total MSW disposed of in the three landfills. Landfill 2, with a surface of approximately 95 ha, has five reception cells, which range in ages from 0 to 11 years, only one of which is still active. This landfill received approximately $8 \%$ of the total MSW during 2010. With a surface of 42.5 ha, and four cells for final disposal, Landfill 3, is the smallest of the three landfills, its cells ranging between 0 and 23 years old, with only one of them currently active. During 2010, it received $4 \%$ of the total MSW. The three landfills have a total of 13 cells. Of these, 9 cells are no longer receiving MSW, and their dates of closure vary from less than a year to 23 years ago.

\section{Materials and methods}

Over a period of two years and every three months, eight samplings covering all the cells of the three landfills were carried out. The relative cover per species in ten $0.25 \mathrm{~m}^{2}$ squares was registered along each of four random transects per cell and sampling date for a total of 4,160 datapoints. At the same points, soil mechanical resistance was measured with a penetrometer at $5,10,15$, and $20 \mathrm{~cm}$ depth intervals. The plants collected were identified according to Cabrera (1963); Cabrera 1965a a; Cabrera 1965b b; Cabrera 1967; Cabrera 1967; Cabrera 1970) and Rúgolo de Agrasar et al. (2005). Specimens of each of the species were deposited at the Departamento de Ciencias Básicas, Universidad Nacional de Luján. The nomenclature followed Zuloaga et al. (1994) and Zuloaga and Morrone (1996); Zuloaga and Morrone 1999aa; Zuloaga and Morrone 1999bb).

Richness and the exponential Shannon diversity index (eH') — which expresses the number of species that would be present in an assemblage in which all species were equally common (Magurran 2004) were calculated for each cell, using Estimates 8 (Colwell 2006). The vegetation cover and the diversity indexes of the different-aged cells, were compared using the Kruskal-Wallis test and the Q statistic (Zar 1999).

The indicator value of each species for the parameter age was calculated in each landfill (McCune and Grace 2002). Multivariate patterns among observations were visualized by means of a non-metric Multidimensional Scaling ordination (NMDS) based on the BrayCurtis distances and to determine the differences between vegetation assemblages in the 
different aged cells, an analysis of similarities (ANOSIM) (Clarke and Warwick 2001) was applied. Each cell was assigned to one of three age categories: 0, 2 and 3 years; 5 to 7 years; and 9; 11 and 23 years. Collected species were classified as native by one hand, and as alien (introduced, adventicious and naturalized) by the other hand, according to Zuloaga et al. (1994) and Zuloaga and Morrone (1996); Zuloaga and Morrone 1999aa; Zuloaga and Morrone 1999bb). Aa Wilcoxon matched paired test was used to compare vegetation cover for both groups, and for annuals and perennials. The Spearman Rank was used to measure the correlation between groups coverage and cell age.

In order to relate the cell's vegetation cover to soil compaction, the level of the soil's resistance to penetration was measured (Al-Adawi and Reeder 1996; Hamza and Anderson 2005). The measurements were made with a $30^{\circ}$ angle cone penotrometer (ASAE Standard S 313). The readings were carried out in the same transects and over the same points where vegetation cover was assessed. The measured values are expressed in megapascals (MPa), and they correspond with the maximum value found for each $5 \mathrm{~cm}$ depth interval. The data were analyzed using a Kruskal-Wallis ANOVA-test.

\section{Results}

The level of vegetation cover varied markedly between cells of different ages since closure. Starting with no vegetation, the level of cover on the cells reached $80 \%$ at the end of five years. This resulted in the cells being very homogeneous, and reaching almost a $100 \%$ cover after 9 years since closure. The cover of the active cells was lower in Landfill 1, the larger and more active landfill, than in the other two: $12 \%$ in Landfill 1, compared to $41 \%$ in Landfill 2 and $59 \%$ in Landfill 3 . Both active and two year old cells were significantly different from the rest of the cells in the three landfills (Fig. 1).

Species richness varied between 6 (SD: 2.24) and 29 (SD: 4.03) species and did not show any relation with the age of the cells. The Exponential Shannon index (eH') varied between 1 and 2.2 and showed no differences when all of the cells were compared. When comparing cells within each landfill, significant differences $(p<0.05)$ were only found in Landfill 1 between the active (eH' median: 1.21) and oldest (5 years old, eH' median: 1.05) cells.

Regarding the floristic composition of the assemblages, a total of 48 species was found. The dominant species was Cynodon dactylon, representing more than $80 \%$ of the cover average in all the cells of up to 9 years of age, and less abundant (between 68 and $76 \%$ ) in the oldest cells. In the active cells, the species with $5 \%$ cover or more were Lotus tenuis and Polygonm aviculare. In the cells of 5 years and older, besides $C$. dactylon they were Bromus catharticus (between 5 and $17 \%$ ), Paspalum dilatatum (7\%) and Brassica nigra (7\%). However, the analysis of the indicator value of species did not shed consistent information. The identity of the species with the greatest indicator value was different for cells of the same age across the different landfills (Table 1).

The NMDS ordination plot did not show any similarity among cells of the same age (Fig. 2), and the similarity analysis ANOSIM performed on the samples from cells of the same age was non-significant (R: 0.046 , ns). Most of the species were native (42\%) and perennials $(62 \%)$. Plant cover was dominated by non-native species in cells of every age $(p<0.005)$. Nonetheless, the results show that as succession progresses the native species were better represented in the older cells (Spearman R: 0.71, $p<0.05$ ), while this relationship was not significant for the non-native species. The results also show that coverage by perennial species was higher than that of annual species. Neither group showed a significant correlation with cell age. Significant differences were found for mechanic resistance (MR) of the soil in cells of 
Fig. 1 Total cover in the cells of landfills 1, 2 and 3, clustered according to age. Symbols: medians; boxes: percentiles 25 and 75; whiskers: min-max. Different letters indicate significant differences (Kruskal-Wallis, $p<0.05$; Q statistic $p<0.05$ )
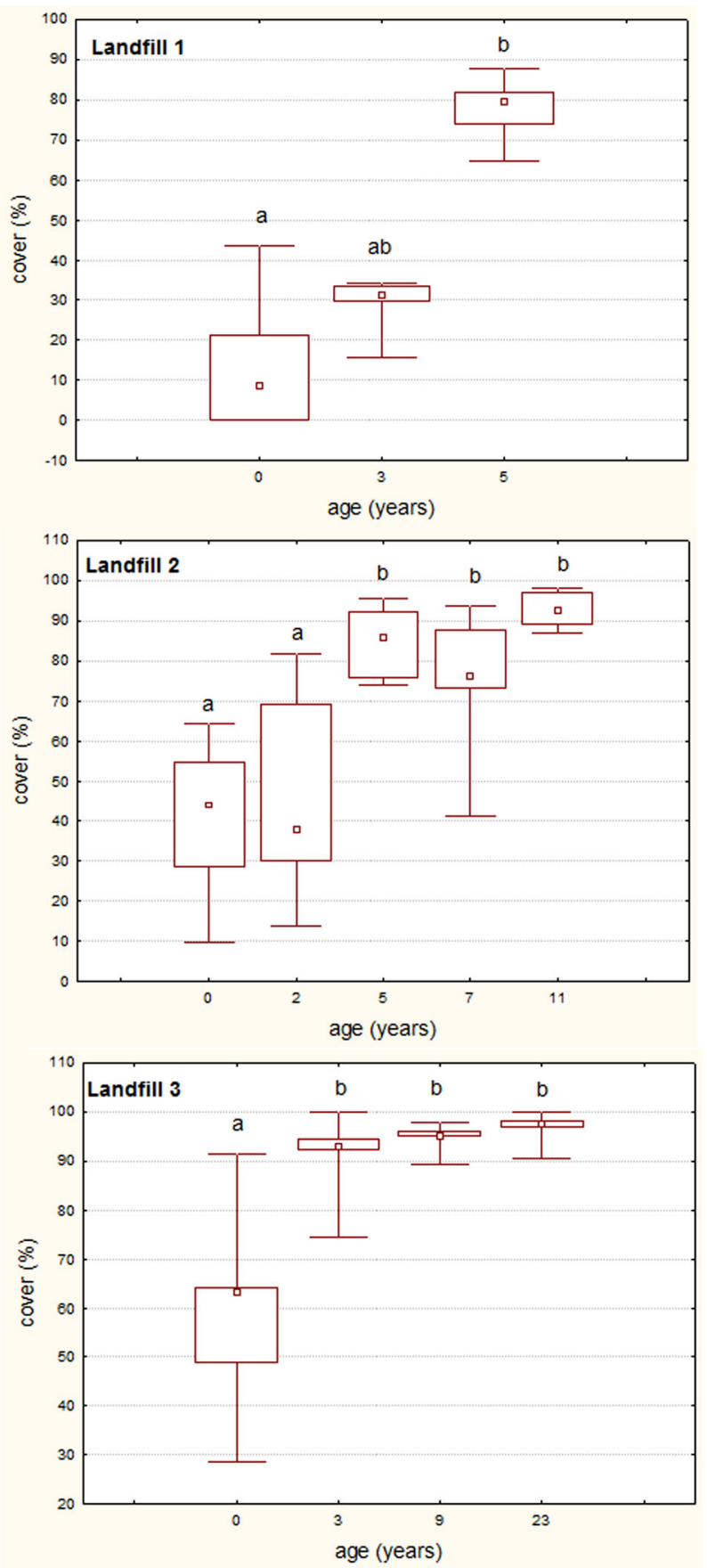

different ages, within the $0-5 \mathrm{~cm}$ range $(p<0.05)$. Starting at year 5 , a decrease in the MR is observed, and starting at year 9, values fall below the critical value for root development (MR $<0.5 \mathrm{MPa}$ ) (Gaitán and Penón 2003) (Fig. 3). For the four depth intervals (0 to $20 \mathrm{~cm}$ ), 
Table 1 Species with highest Indicator Value (\% of perfect indication) in the cells of different ages, in the three landfills

\begin{tabular}{llll}
\hline Species & Indicator Value & $\begin{array}{l}\text { Cell age (years } \\
\text { since closure) }\end{array}$ & Landfill \\
\hline Malvella leprosa & 77.30 & 0 & 3 \\
Bromus catharticus & 64.50 & 11 & 2 \\
Cynodon dactylon & 61.44 & 5 & 1 \\
Eleocharis bonariensis & 47.56 & 23 & 3 \\
Polygonum aviculare & 43.80 & 0 & 2 \\
Matricaria recutita & 40.00 & 9 & 2 \\
Paspalum dilatatum & 40.00 & 3 & 1 \\
Cynodon dactylon & 38.00 & 3 & 3 \\
Paspalum dilatatum & 35.90 & 5 & 2 \\
Ambrosia tenuifolia & 31.30 & 2 & 2 \\
\hline
\end{tabular}

significant differences $(p<0.05)$ were only observed between the cell aged 23 and the cell aged 0 (Fig. 4).

\section{Discussion}

The three landfills receiving MSW from the MABA (Buenos Aires, Argentina) were synchronically studied to assess whether there was a pattern relating vegetation to cell age, despite the differences in expanse and level of activity of the landfills.

The data show that vegetation cover is significantly lower for those cells which have been closed within the two previous years, and that from 5 years on, the cover is consistently higher than $80 \%$. The vegetation is dominated by perennial herbs, thus mitigating erosion, signs of which are clearly seen at the cells' slopes when recently formed with the covering substratum.

The results for the soil's mechanic resistance suggest an evolution in this soil trait. During the first stages, in which there is considerable machinery traffic, MR is variable; but in advanced stages, it becomes more uniform. At about five years since cell closure, MR falls below 0.5 MPa -a critical value for root development (Gaitán and Penón 2003)- which coincides with an increase in vegetation cover. This critical value means that fine root exploration of the soil mass does not encounter resistance, probably due to an increased

Fig. 2 Non-metric multidimensional scaling (NMDS) ordination plot of the cells aged $0 ; 2 ; 3 ; 5 ; 7$; 9; 11 and 23 years) in the three landfills: $+: 1 ; \Delta: 2 ; \square: 3$

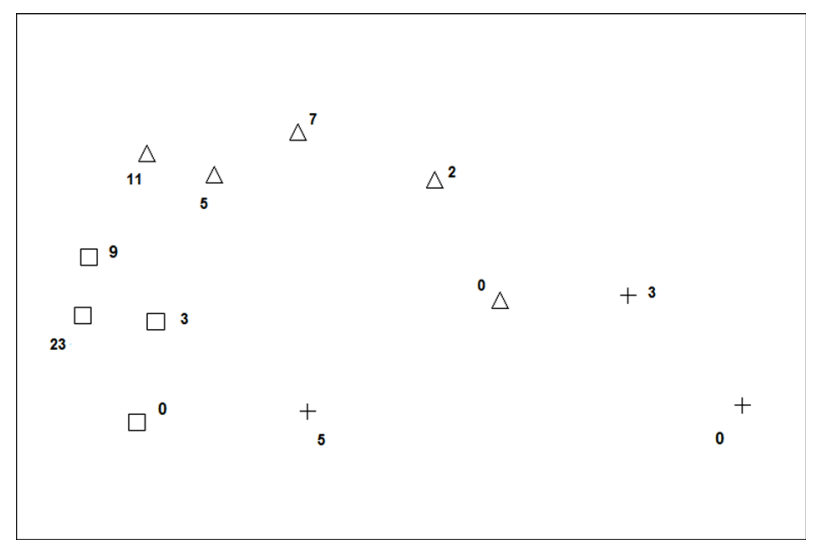


Fig. 3 Plant cover (\%) $\square$ and mechanical resistance (MR) $\$$ of the different cells clustered according to age. MR values (Mpa) for the top $5 \mathrm{~cm}$ of soil in the three landfills. The Critical value (CV) of $0.5 \mathrm{Mpa}$ is shown. The symbols indicate means; boxes: Mean $\pm \mathrm{SE}$ and whiskers: Mean $\pm \mathrm{SD}$

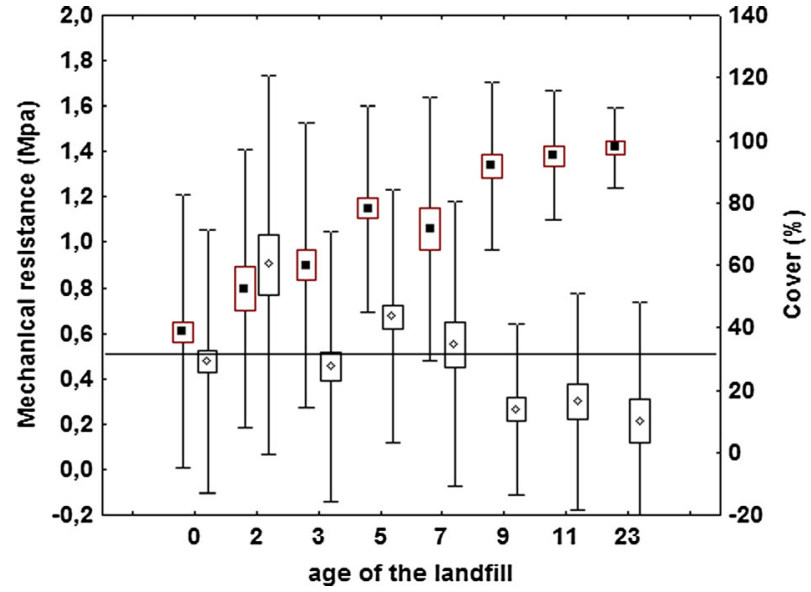

macroporosity, which in turn is attributable to the accumulated effect of the vegetation cover. At the same time, more macroporosity leads to enhanced soil aeration and hydraulic conductivity (Botta et al. 2002).

Regarding plant diversity, no pattern was found in relation to cell age, contrary to what was indicated by Nagendran et al. (2006) and Ettala et al. (1988), who found clear, though opposite, tendencies relating diversity to cell age. Ordination analyses showed no evidence of a pattern either; moreover, the NMDS shows more similarity among cells from the same landfill than among similarly aged cells from different landfills. No common age indicator species were found, given that the identity of the species varied between landfills. This means that even though there were variations in the community composition with time, the heterogeneity of the ensembles between the 3 places prevented the configuration of an age linked pattern.

The predominance of Cynodon dactylon in all the cells of the three landfills and across all the cell ages is remarkable. This exotic species possesses characteristics that facilitate its survival and expansion, in both active and old cells. In the first ones, as it is tolerant to high stress environments, it grows and expands rapidly on top of the naked substratum; in the second ones, thanks to its creeping habits, it can withstand grass mowing. C. dactylon was also

Fig. 4 Mechanical resistance values for each of the $5 \mathrm{~cm}$ intervals: $\mathbf{} 5 \mathrm{~cm}, \bullet 10 \mathrm{~cm}, \boldsymbol{\Delta} 15 \mathrm{~cm}, \bullet$ $20 \mathrm{~cm}$, in all the cells of the three landfills taken together. The Critical value (full black line) of 0.5 Mpa is shown. The symbols indicate means; boxes: Mean $\pm \mathrm{SE}$ and whiskers: Mean $\pm \mathrm{SD}$

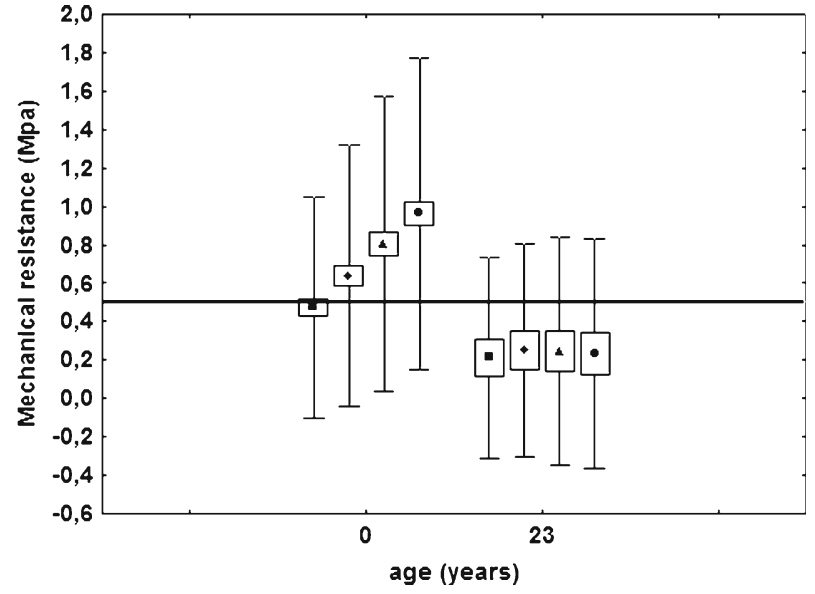


found to be a dominant species in other landfills; however, unlike our results, it was more frequently associated to areas with established vegetation than to the active, or still frequently disturbed, cells (Trotter and Cooke 2005).

Taking into account the origin of the species some regularities arise: exotics are dominant along the whole studied succession; meanwhile, natives gain in proportionality consistently with the age of the cells. Therefore, native species seem to be sensitive to the changes occurring in the cells' characteristics along the succession.

The different analyses performed on the data, coincide in that no common assemblages forming particular succesional stages neither stage characteristic species can be identified within the first 23 years after closure. Along the whole studied successional period the vegetation ensemble is dominated by exotic herbs, rendering acommunity consistent with the typical graminoid, grassy landscape of this ecoregion. In this sense, we also found that the dominant and indicator species of the young cells predominantly belong to plant families bearing a great proportion of invasive species (Rejmánek 2000). Alien species have characteristics that enhance their invasiveness in altered environments, and even in the case that they share traits with native dominants, an alteration of the original community may facilitate their expansion. In this study most of the indicator species, both of young and old cells, and those having more than $5 \%$ cover, are characteristic of perturbed environments -except for the marsh representatives Galega sp. and Lotus sp. Nevertheless alien species are accompanied by mature community native grasses.

The variation in species characteristics along the succession is important because they change the system's function. Stages in successions have long been described through the biological characteristics of the dominant species (Noble and Slatyer 1980). Some shared plant traits found among indicators of young cells and dominant species include the presence rhizomes, bud-bearing roots, and creeping habits.

Even though in the Pampa region the natural vegetation has been mostly replaced, in these landfills we found that native species reach $42 \%$. Among them, some of the dominant species belong to the climax pampean steppe, e.g. Bromus catarthicus and Paspalum dilatatum. This fact suggests that these altered areas have a potential conservation value, but also that spontaneous succession and passive ecosystem restoration is not complete after 23 years, given that native species reach around $20 \%$ of cover in the oldest modules. Therefore, an orientated human intervention would be necessary to achieve a dominance of natives. In conclusion, the data collected shows that in the three landfills a high percentage of vegetation cover is to be found in the cells which have been closed for at least five years. Neither diversity, nor species composition can be related to the time elapsed since the closing of the cells. There are no species with high indicator value common to the different cells of the same age.

Daily input of waste and the way in which the sites are operated after closure, both affect vegetation richness and diversity. However, this effect is not strong enough for a significant change in total cover to be observed in cells aged 5 or more years. Additionally, vegetation cover is an easily estimated variable, which reflects accurately the time elapsed since the closing of the cell, and responds robustly to the different operations occurring after cell closure.

Technosols akin to the ones studied in this work are common in many places over the world, where landfills are used as a way to dispose MSW. After closure, these landfill locations need to be reused as part of land use plans, especially around big cities were this disposal technology is mostly used. Extending this study to cells aged more than 23 years after closure might shed some other important trends on plant secondary succession over these technosols. However, the vegetation changes seem to be quite slow after a few years of succession, and a grassland landscape tends to be established. 
Acknowledgments The authors thank Brian Lartigau for laboratory and fieldwork assistance and Violeta Corace for help with the english version of this article the translation. This research was partially founded by Universidad Nacional de Luján.

\section{References}

Al-Adawi SS, Reeder RC (1996) Compaction and subsoiling effects on corn and soybean yields and soil physical properties. Trans ASAE 39:1641-1649

Bilenca D, Miñarro F (2004) Identificación de Áreas Valiosas de Pastizal (AVP) en las Pampas y Campos de Argentina, Uruguay y Sur de Brasil. Fundación Vida Silvestre, Puerto Iguazú

Botta G, Jorajuria D, Draghi F (2002) Compactación subsuperficial del suelo producida por distintas intensidades de transito en un sistema frutícola. ISSN 0213-5000(17):15-26

Cabrera AL (1963) Flora de la provincia de Buenos Aires. Parte 6, compositae. INTA, Puerto Iguazú

Cabrera AL (1965a) Flora de la provincia de Buenos Aires. Parte 4, Oxalidáceas a Umbelliferae. INTA, Puerto Iguazú

Cabrera AL (1965b) Flora de la provincia de Buenos Aires. Parte 5, ericáceas a cliceráceas. INTA, Puerto Iguazú

Cabrera AL (1967) Flora de la provincia de Buenos Aires. Parte 3, piperáceas a leguminosas. INTA, Puerto Iguazú

Cabrera AL (1970) Flora de la provincia de Buenos Aires. Parte 2, gramíneas. INTA, Puerto Iguazú

Cabrera AL, Willink A (1980) Biogeografía de América Latina, 2nd Monografía 13. Serie de Biología. Secretaría General de la Organización de los Estados Americanos. Washington DC. EEUU

CEAMSE (2011) Artículos de la categoría: complejos ambientales (Complejo Ambiental Ensenada, Complejo Ambiental González Catán, Complejo Ambiental Norte III). http://ceamse.gov.ar/category/gestionrsupreservacion-recursos-naturales/complejos-ambientales/. Accessed 27 July 2012

Chan YSG, Chub LM, Wong MH (1997) Influence of landfill factors on plants and soil fauna an ecological perspective. Environ Pollut 97(1-2):39-44

Clarke KR, Warwick RM (2001) Changes in marine communities: an approach to statistical analysis and interpretation. PRIMER-E: Plymouth.

Colwell RK (2006) EstimatesS: statistical estimation of species richness and shared species from samples Version 8.2.0. Persistent URL < purl.oclc.org/estimates>

Ettala MO, Yrjonen KM, Rossi EJ (1988) Vegetation coverage at sanitary landfills in Finland. Waste Manag Res 6:281-289

Gaitán JJ, Penón E (2003) Efecto de la resistencia mecánica del suelo sobre la densidad de raíces finas de Eucalyptus globulus. Investig Agrar: Sist Recur Forestal 12(2):125-130

Hamza MA, Anderson W (2005) Soil compaction in cropping systems. A review of the nature, causes and possible solutions. Soil Tillage Res 82:121-145

Hartley W, Uffindell L, Plumb A, Rawlinson AH, Putwain P, Dickinson NM (2008) Assessing biological indicators for remediated anthropogenic urban soils. Sci Total Environ 05:358-369

INDEC (2010) Censo Nacional de Población, Hogares y VIviendas 2010. http://www.censo2010.indec.gov.ar/. Accessed 24 July 2012

Lan C, Wong M (1994) Environmental factors affecting growth of grasses, herbs and woody plants on a sanitary landfill. J Environ Sci 6:504-513

Lehmann A, Stahr K (2007) Nature and significance of anthropogenic urban soils. J Soils Sediments 7:247-60

Magurran AE (2004) Measuring biological diversity. Blackwell, Oxford

Martino D (2004) Conservación de praderas en el Conosur: valoración de las áreas protegidas existentes. Ecosistemas 13 (2):114-123

McCune G, Grace J (2002) Analysis of ecological communities. Blackwell, Oxford

Nagendran R, Selvam A, Kurian J, Chiemchaisri C (2006) Phytoremediation and rehabilitation of municipal solid waste landfills and dumpsites: A brief review. Waste Manag 26:1357-1369

Noble IR, Slatyer RO (1980) The use of vital attributes to predict successional changes in plant communities subject to recurrent disturbances. Vegetatio 43:5-21

Rejmánek M (2000) Invasive plants: approaches and predictions. Austral Ecol 25:497-506

Rúgolo de Agrasar Z, Steibel P, Troiani H (2005) Manual ilustrado de las Gramíneas de la provincia de La Pampa. U.N. La Pampa and U.N. Río Cuarto, Río Cuarto

Simmons E (1999) Restoration of landfill sites for ecological diversity. Waste Manag Res 17:511-519

Trotter DH, Cooke JA (2005) Influence of landfill gas on the microdistribution of grass establishment through natural colonization. Environ Manag 35(3):303-310

Zar JH (1999) Biostatistical analysis. Prentice Hall, New Jersey 
Zuloaga FO, Morrone O (1996) Catálogo de las Plantas Vasculares de la República Argentina. I. Pteridophyta, Gymnospermae y Angiospermae (Monocotyledoneae). Monogr Syst Bot Mo Bot Gard 60:1-323

Zuloaga FO, Morrone O (1999a) Catálogo de las plantas vasculares de la República Argentina. II. Acanthaceae euphorbiaceae (dicotyledoneae). Monogr Syst Bot Mo Bot Gard 74:1-621

Zuloaga FO, Morrone O (1999b) Catálogo de las plantas vasculares de la República Argentina. II. Fabaceaezygophyllaceae (dicotyledoneae). Monogr Syst Bot Mo Bot Gard 74:1-1269

Zuloaga FO, Nicora EG, Rúgolo de Agrasar Z, Morrone O, Pensiero J, Cialdella AM (1994) Catálogo de la familia poaceae en la República Argentina. Monogr Syst Bot Mo Bot Gard 47:1-178 